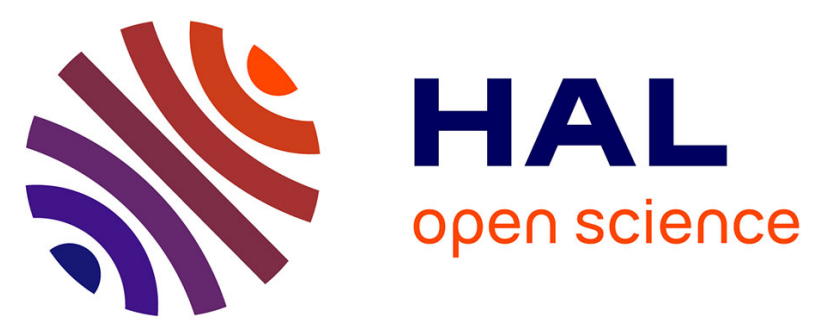

\title{
Antimicrobial Susceptibility Pattern and Biochemical Characteristics of Staphylococcus aureus: Impact of Bio field Treatment
}

Mahendra Kumar Trivedi, Shrikant Patil, Harish Shettigar, Sambhu Charan

Mondal, Snehasis Jana

\section{To cite this version:}

Mahendra Kumar Trivedi, Shrikant Patil, Harish Shettigar, Sambhu Charan Mondal, Snehasis Jana. Antimicrobial Susceptibility Pattern and Biochemical Characteristics of Staphylococcus aureus: Impact of Bio field Treatment. Journal of Microbial \& Biochemical Technology, 2015, 7 (4), pp.238-241. hal-01502112

\section{HAL Id: hal-01502112 \\ https://hal.science/hal-01502112}

Submitted on 5 Apr 2017

HAL is a multi-disciplinary open access archive for the deposit and dissemination of scientific research documents, whether they are published or not. The documents may come from teaching and research institutions in France or abroad, or from public or private research centers.
L'archive ouverte pluridisciplinaire HAL, est destinée au dépôt et à la diffusion de documents scientifiques de niveau recherche, publiés ou non, émanant des établissements d'enseignement et de recherche français ou étrangers, des laboratoires publics ou privés.

\section{(c)(1)}

Distributed under a Creative Commons Attribution| 4.0 International License 


\title{
Antimicrobial Susceptibility Pattern and Biochemical Characteristics of Staphylococcus aureus. Impact of Bio field Treatment
}

Mahendra Kumar Trivedi ${ }^{1}$, Shrikant Patil ${ }^{1}$, Harish Shettigar ${ }^{1}$, Sambhu Charan Mondal ${ }^{2}$ and Snehasis Jana ${ }^{2 *}$

${ }^{1}$ Trivedi Global Inc., 10624 S Eastern Avenue Suite A-969, Henderson, NV 89052, USA

${ }^{2}$ Trivedi Science Research Laboratory Pvt. Ltd., Hall-A, Chinar Mega Mall, Chinar Fortune City, Bhopal, Madhya Pradesh, India

\begin{abstract}
Study background: Staphylococci are widespread in nature, mainly found on the skin and mucous membranes. Staphylococcus aureus ( $S$. aureus) is the key organism for food poisoning due to massive production of heat stable exotoxins. The current study was attempted to investigate the effect of biofield treatment on antimicrobial susceptibility pattern and biochemical characteristics of S. aureus (ATCC 25923).

Methods: S. aureus cells were procured from MicroBioLogics in sealed packs bearing the American Type Culture Collection (ATCC 25923) number and stored according to the recommended storage protocols until needed for experiments. Revived and lyophilized state of ATCC strains of S. aureus were selected for the study. Both revived (Group; Gr. II) and lyophilized (Gr. III) strain of S. aureus were subjected to Mr. Trivedi's biofield treatment. Revived treated cells were assessed on day 5 and day 10 while lyophilized treated cells on day 10 only. After biofield treatment both treated cells were analysed for its antimicrobial sensitivity, minimum inhibitory concentration value, biochemical reactions and biotype number with respect to control $(\mathrm{Gr} . \mathrm{I})$.
\end{abstract}

Results: The antimicrobial susceptibility and minimum inhibitory concentration of $S$. aureus showed significant $(86.67 \%)$ alteration in lyophilized cells while no alteration was found in revived treated cells as compared to control. It was observed that overall $37.93 \%$ (eleven out of twenty nine) biochemical reactions were altered in the treated groups with respect to control. Moreover, biotype numbers were substantially changed in revived treated cells, Gr. II (303137, Staphylococcus capitis subsp. ureolyticus) on day 5 and in lyophilized treated cells, Gr. III (767177, S. cohnii subsp. urealyticum) on day 10 as compared to control (307016, S. aureus).

Conclusion: The result suggested that biofield treatment has significant impact on $S$. aureus in lyophilized treated cells with respect to antimicrobial susceptibility, MIC values and biochemical reactions pattern. Apart from these, biotype numbers with new species were observed in revived treated group on day 5 as Staphylococcus capitis subsp. ureolyticus and in lyophilized cells as Staphylococcus cohnii subsp. urealyticum with respect to control, i.e., S. aureus.

Keywords: Staphylococcus aureus; Antimicrobial susceptibility; Biofield treatment; Biochemical reaction; Biotype

\section{Introduction}

Staphylococci (staph) are Gram-positive spherical bacteria that occur in microscopic clusters resembling to grapes like structure. Staphylococcus aureus (S. aureus) is considered as the third most important cause of food-borne disorders in the world [1]. It is estimated that in US alone food-borne illnesses affect 6 to 80 million people each year, causing up to 9000 deaths [2]. S. aureus transmitted mainly through foodstuffs and the important cause of food contamination including milk products and beef $[3,4]$. S. aureus mainly invades through the nasal passages, but it is also found regularly in most other anatomical locales, including the skin, oral cavity and gastrointestinal tract. $S$. aureus has developed resistance to most classes of antimicrobial agents. Penicillin is the drug of choice to treat staphylococcus infection but due to penicillinase or $\beta$-lactamase enzyme that destroy the penicillin, leads to resistance against $S$. aureus [5]. Therefore, some alternative strategies are needed to treat against resistant strains of staphylococci. Biofield treatment has been known as alternative approach which may be useful to alter the resistance pattern in staphylococcus infected patients.

Afterward, Harold Saton Burr had performed the detailed studies on the correlation of electric current with physiological process and concluded that every single process in the human body had an electrical significance [6]. Recently, it was discovered that all the electrical process happening in body have strong relationship with magnetic field as required by Ampere's law, which states that the moving charge produces magnetic fields in surrounding space $[7,8]$. Thus, the human body emits the electromagnetic waves in form of bio-photons, which surrounds the body and it is commonly known as biofield. Therefore, the biofield consists of electromagnetic field, being generated by moving electrically charged particles (ions, cell, molecule etc.) inside the human body. According to Rivera-Ruiz, reported that electrocardiography has been extensively used to measure the biofield of human body [9]. Thus, human has the ability to harness the energy from environment or universe and can transmit into any living or nonliving object(s) around the Globe. The objects always receive the energy and responding into useful way that is called biofield energy and the process is known as biofield treatment. Mr. Mahendra Trivedi's biofield treatment has been known to transform the structural, physical and thermal properties of several metals in material science [10-12], improved the overall productivity of crops $[13,14]$, altered

*Corresponding author: Snehasis Jana, Trivedi Science Research Laboratory Pvt. Ltd., Hall-A, Chinar Mega Mall, Chinar Fortune City, Bhopal, Madhya Pradesh, India, Tel: +91-755-6660006; E-mail: publication@trivedisrl.com

Received July 09, 2015; Accepted July 23, 2015; Published July 30, 2015

Citation: Trivedi MK, Patil S, Shettigar H, Mondal SC, Jana S (2015) Antimicrobial Susceptibility Pattern and Biochemical Characteristics of Staphylococcus aureus: Impact of Bio field Treatment. J Microb Biochem Technol 7: 238-241. doi:10.4172/1948-5948.1000215

Copyright: @ 2015 Trivedi MK, et al. This is an open-access article distributed under the terms of the Creative Commons Attribution License, which permits unrestricted use, distribution, and reproduction in any medium, provided the original author and source are credited. 
Citation: Trivedi MK, Patil S, Shettigar H, Mondal SC, Jana S (2015) Antimicrobial Susceptibility Pattern and Biochemical Characteristics of Staphylococcus aureus: Impact of Bio field Treatment. J Microb Biochem Technol 7: 238-241. doi:10.4172/1948-5948.1000215

characteristics features of microbes [15-17] and improved growth and anatomical characteristics of various medicinal plants $[18,19]$.

Due to the clinical significance of this organism and literature reports on biofield, the present work was undertaken to evaluate the impact of biofield treatment on S. aureus in relation to antimicrobials susceptibility and biotyping based on various biochemical characters.

\section{Materials and Methods}

S. aureus, American Type Culture Collection (ATCC 25923) strains were procured from MicroBioLogics, Inc., USA, in two sets A and B. Two different sealed packs were stored with proper storage conditions until further use. All the tested antimicrobials and biochemicals were procured from Sigma-Aldrich (MA, USA). The antimicrobial susceptibility, biochemical reactions and biotype number were estimated with the help of MicroScan Walk-Away (Dade Behring Inc., West Sacramento, CA, USA) using Positive Breakpoint Combo 30 (PBPC 30) panel with respect to control group.

\section{Experimental design}

Two ATCC 25923 samples A and B of S. aureus were grouped (Gr.). ATCC A sample was revived and divided into two parts Gr.I (control) and Gr.II (revived); likewise, ATCC B was labeled as Gr.III (lyophilized).

\section{Biofield treatment strategy}

The Gr. I remained as untreated. The treatment Gr. II and III in sealed pack were handed over to Mr. Trivedi for biofield treatment under laboratory condition. Mr. Trivedi provided the treatment through his energy transmission process to the treated groups ( $\mathrm{Gr}$. II and Gr. III) without touching the samples. After treatment, all treated samples were handed over in the same condition and stored for analysis. Gr.II was assessed at two time point, i.e., on day 5 and 10 and Gr. III was assessed on day 10. After biofield treatment, all the groups (control and treated) were investigated on day 10 for antimicrobial susceptibility, biochemical reactions pattern and biotyping.

\section{Antimicrobial susceptibility test}

Investigation of antimicrobial susceptibility of $S$. aureus was carried out with the help of automated instrument, MicroScan WalkAway ${ }^{\circledR}$ using PBPC 30 panel. The tests carried out on MicroScan were miniaturizated of the broth dilution susceptibility test that have been dehydrated. Briefly, the standardized suspension of $S$. aureus were inoculated, rehydrated, and then subjected to incubation for 16 hours at $35^{\circ} \mathrm{C}$. The detailed experimental procedures and conditions were followed as per the manufacturer's instructions. The antimicrobial susceptibility pattern (S: Susceptible, R: Resistant; and BLAC: Beta lactamase positive) and minimum inhibitory concentration (MIC) were determined by observing the lowest antimicrobial concentration showing inhibition of growth [20].

\section{Biochemical reaction studies}

Biochemical reactions of $S$. aureus were determined using MicroScan Walk-Away, system with PBPC 30 panel [21].

\section{Identification of organism by biotype number}

The biotype number of $S$. aureus was determined on MicroScan Walk-Away ${ }^{\circledR}$ processed panel data report with the help of biochemical reactions data [22].

\section{Results and Discussion}

\section{Antimicrobial susceptibility test}

The outcome of $S$. aureus susceptibility pattern and MIC values of tested antimicrobials after biofield treatment are summarized in Tables 1 and 2, respectively. The data were analyzed and compared with respect to control. Study was carried out in thirty antimicrobials. The treated cells of $S$. aureus showed a significant (86.67\%) alteration (twenty six out of thirty) in antimicrobial sensitivity pattern ( $\mathrm{S}$ to $\mathrm{R}$ ) and MIC values in the lyophilized treated Gr. III on day 10 as compared with control. Four, out of thirty tested antimicrobials did not show any responses in lyophilized treated cells of $S$. aureus. Out of twenty six antimicrobials two antibiotics (ampicillin and penicillin), i.e., $6.67 \%$ did not show any change because $S$. aureus has the ability to produce $\beta$-lactamases or penicillinase enzyme which breakdown the $\beta$-lactam ring present in penem heteronucleus [23]. The effect of biofield treatment had revealed that the antibiotic chloramphenicol converted the sensitivity pattern from $\mathrm{S} \rightarrow \mathrm{R}$ with corresponding MIC value $(\leq 8$ to $>16 \mu \mathrm{g} / \mathrm{mL}$ ) in revived treated cells (Gr. II) and in lyophilized treated cells (Gr. III) on day 10 with respect to control. Three out of thirty $(10 \%)$ antimicrobials did not show any alteration of MIC values in all the treated groups as compared to control (Table 2). The treated cells

\begin{tabular}{|c|c|c|c|c|c|}
\hline \multirow[t]{3}{*}{ S. No. } & \multirow[t]{3}{*}{ Antimicrobial } & \multicolumn{4}{|c|}{ Type of Response } \\
\hline & & \multirow[t]{2}{*}{ Gr. I } & \multicolumn{2}{|c|}{ Gr. II } & \multirow[t]{2}{*}{ Gr. III } \\
\hline & & & Day 5 & Day 10 & \\
\hline 1. & Amoxicillin/ k-clavulanate & $\mathrm{S}$ & $\mathrm{S}$ & $\mathrm{S}$ & $\mathrm{R}$ \\
\hline 2. & Ampicillin/sulbactam & S & S & $\mathrm{S}$ & $\mathrm{R}$ \\
\hline 3. & Ampicillin & S & $S$ & $\mathrm{~S}$ & BLAC \\
\hline 4. & Azithromycin & S & $S$ & $\mathrm{~S}$ & $\mathrm{R}$ \\
\hline 5. & Cefazolin & S & S & S & $\mathrm{R}$ \\
\hline 6. & Cefepime & $S$ & S & $S$ & $\mathrm{R}$ \\
\hline 7. & Cefotaxime & $S$ & $S$ & S & $\mathrm{R}$ \\
\hline 8. & Ceftriaxone & $S$ & $S$ & $S$ & $\mathrm{R}$ \\
\hline 9. & Cephalothin & $S$ & $S$ & $S$ & $\mathrm{R}$ \\
\hline 10. & Chloramphenicol & $S$ & $S$ & $\mathrm{R}$ & $\mathrm{R}$ \\
\hline 11. & Ciprofloxacin & $S$ & $S$ & $S$ & $\mathrm{R}$ \\
\hline 12. & Clindamycin & $S$ & $S$ & $S$ & $\mathrm{R}$ \\
\hline 13. & Erythromycin & $S$ & $S$ & $S$ & $\mathrm{R}$ \\
\hline 14. & Gatifloxacin & S & S & $\mathrm{S}$ & $\mathrm{R}$ \\
\hline 15. & Gentamicin & S & $S$ & $\mathrm{~S}$ & $\mathrm{R}$ \\
\hline 16. & Imipenem & $S$ & $S$ & $S$ & $\mathrm{R}$ \\
\hline 17. & Levofloxacin & $S$ & $S$ & $S$ & $\mathrm{R}$ \\
\hline 18. & Linezolid & $S$ & $S$ & $S$ & - \\
\hline 19. & Moxifloxacin & $S$ & $S$ & $S$ & $\mathrm{R}$ \\
\hline 20. & Nitrofurantoin & - & - & - & - \\
\hline 21. & Norfloxacin & - & - & - & - \\
\hline 22. & Ofloxacillin & S & $S$ & $\mathrm{~S}$ & $\mathrm{R}$ \\
\hline 23. & Oxacillin & $S$ & S & $S$ & $\mathrm{R}$ \\
\hline 24. & Penicillin & $S$ & $S$ & $S$ & BLAC \\
\hline 25. & Piperacillin/tazobactam & $S$ & $S$ & $S$ & - \\
\hline 26. & Rifampin & $S$ & $S$ & $S$ & $\mathrm{R}$ \\
\hline 27. & Synercid & $S$ & $S$ & $S$ & $\mathrm{R}$ \\
\hline 28. & Tetracycline & S & $S$ & $S$ & $\mathrm{R}$ \\
\hline 29. & $\begin{array}{l}\text { Trimethoprim/ } \\
\text { sulfamethoxazole }\end{array}$ & $S$ & S & $S$ & $\mathrm{R}$ \\
\hline 30. & Vancomycin & S & $S$ & $\mathrm{~S}$ & $\mathrm{R}$ \\
\hline
\end{tabular}

R: Resistant; S: Susceptible; Gr.: Group; ‘-’: Not reported; BLAC: Beta lactamase positive

Table 1: Antibiogram of Staphylococcus aureus: Effect of biofield treatment on antimicrobial susceptibility. 
Citation: Trivedi MK, Patil S, Shettigar H, Mondal SC, Jana S (2015) Antimicrobial Susceptibility Pattern and Biochemical Characteristics of Staphylococcus aureus: Impact of Bio field Treatment. J Microb Biochem Technol 7: 238-241. doi:10.4172/1948-5948.1000215

\begin{tabular}{|c|c|c|c|c|c|}
\hline \multirow{3}{*}{$\begin{array}{l}\text { S. } \\
\text { No. }\end{array}$} & \multirow[t]{3}{*}{ Antimicrobial } & \multicolumn{4}{|c|}{ Type of Response } \\
\hline & & \multirow[t]{2}{*}{ Gr. I } & \multicolumn{2}{|c|}{ Gr. II } & \multirow[t]{2}{*}{ Gr. III } \\
\hline & & & Day 5 & Day 10 & \\
\hline 1. & Amoxicillin/ k-clavulanate & $\leq 4 / 2$ & $\leq 4 / 2$ & $\leq 4 / 2$ & $>4 / 2$ \\
\hline 2. & Ampicillin/sulbactam & $\leq 8 / 4$ & $\leq 8 / 4$ & $\leq 8 / 4$ & $>16 / 8$ \\
\hline 3. & Ampicillin & $\leq 0.25$ & $\leq 0.25$ & $\leq 0.25$ & $>8$ \\
\hline 4. & Azithromycin & $\leq 2$ & $\leq 2$ & $\leq 2$ & $>4$ \\
\hline 5. & Cafazolin & $\leq 8$ & $\leq 8$ & $\leq 8$ & $>16$ \\
\hline 6. & Cefepime & $\leq 8$ & $\leq 8$ & $\leq 8$ & $>16$ \\
\hline 7. & Cefotaxime & $\leq 8$ & $\leq 8$ & $\leq 8$ & $>32$ \\
\hline 8. & Ceftriaxone & $\leq 8$ & $\leq 8$ & $\leq 8$ & $>32$ \\
\hline 9. & Cephalothin & $\leq 8$ & $\leq 8$ & $\leq 8$ & $>16$ \\
\hline 10 & Chloramphenicol & $\leq 8$ & $\leq 8$ & $>16$ & $>16$ \\
\hline 11. & Ciprofloxacin & $\leq 1$ & $\leq 1$ & $\leq 1$ & $>2$ \\
\hline 12. & Clindamycin & $\leq 0.5$ & $\leq 0.5$ & $\leq 0.5$ & $>2$ \\
\hline 13. & Erythromycin & $\leq 0.5$ & $\leq 0.5$ & $\leq 0.5$ & $>4$ \\
\hline 14. & Gatifloxacin & $\leq 2$ & $\leq 2$ & $\leq 2$ & $>4$ \\
\hline 15. & Gentamicin & $\leq 4$ & $\leq 4$ & $\leq 4$ & $>8$ \\
\hline 16. & Imipenem & $\leq 4$ & $\leq 4$ & $\leq 4$ & $\leq 4$ \\
\hline 17. & Levofloxacin & $\leq 2$ & $\leq 2$ & $\leq 2$ & $>4$ \\
\hline 18. & Linezolid & $\leq 2$ & $\leq 2$ & $\leq 2$ & $>4$ \\
\hline 19. & Moxifloxacin & $\leq 2$ & $\leq 2$ & $\leq 2$ & $>4$ \\
\hline 20. & Nitrofurantoin & $\leq 32$ & $\leq 32$ & $\leq 32$ & $\leq 32$ \\
\hline 21. & Norfloxacin & $\leq 4$ & $\leq 4$ & $\leq 4$ & $>8$ \\
\hline 22. & Ofloxacillin & $\leq 2$ & $\leq 2$ & $\leq 2$ & $>4$ \\
\hline 23. & Oxacillin & $\leq 0.25$ & $\leq 0.25$ & $\leq 0.25$ & $>2$ \\
\hline 24. & Penicillin & $\leq 0.03$ & $\leq 0.03$ & $\leq 0.03$ & $>8$ \\
\hline 25. & Piperacillin/tazobactam & $\leq 4$ & $\leq 4$ & $\leq 4$ & - \\
\hline 26. & Rifampin & $\leq 1$ & $\leq 1$ & $\leq 1$ & $>2$ \\
\hline 27. & Synercid & $\leq 1$ & $\leq 1$ & $\leq 1$ & $>2$ \\
\hline 28. & Tetracycline & $\leq 4$ & $\leq 4$ & $\leq 4$ & $>8$ \\
\hline 29. & $\begin{array}{l}\text { Trimethoprim/ } \\
\text { sulfamethoxazole }\end{array}$ & $\leq 2 / 38$ & $\leq 2 / 38$ & $\leq 2 / 38$ & $>2 / 38$ \\
\hline 30. & Vancomycin & $\leq 2$ & $\leq 2$ & $\leq 2$ & $>16$ \\
\hline
\end{tabular}

\begin{tabular}{|c|c|c|c|c|c|c|}
\hline \multirow[t]{3}{*}{ S. No. } & \multirow[t]{3}{*}{ Code } & \multirow[t]{3}{*}{ Biochemical } & \multirow[t]{3}{*}{ Gr. I } & \multicolumn{3}{|c|}{ Type of Response } \\
\hline & & & & \multicolumn{2}{|c|}{ Gr. II } & \multirow[t]{2}{*}{ Gr. III } \\
\hline & & & & Day 5 & Day 10 & \\
\hline 1. & ARA & Arabinose & - & - & - & - \\
\hline 2. & ARG & Arginine & - & + & + & + \\
\hline 3. & BAC & Bacillosamine & + & + & + & + \\
\hline 4. & BE & Bile esculin & - & - & - & - \\
\hline 5. & $\mathrm{BL}$ & Beta lactamases & - & - & - & + \\
\hline 6. & $\mathrm{CV}$ & Crystal violet & - & - & + & + \\
\hline 7. & HEM & Hemolysin & NR & NR & NR & NR \\
\hline 8. & IDX & Indoxyl phosphatase & - & - & - & - \\
\hline 9. & INU & Inulin & - & - & - & - \\
\hline 10. & LAC & Acidification Lactose & + & + & + & + \\
\hline 11. & MAN & Mannitol & + & + & + & + \\
\hline 12. & MNS & Mannose & - & + & + & + \\
\hline 13. & MS & Micrococcus screen & + & + & + & + \\
\hline 14. & NACL & Sodium chloride & + & + & + & + \\
\hline 15. & NIT & Nitrate & + & + & + & + \\
\hline 16. & NOV & Novobiocin & - & - & - & + \\
\hline 17. & OPT & Optochin & + & + & + & + \\
\hline 18. & PGR & Glycosidase* & - & - & - & + \\
\hline 19. & PGT & Glycosidase\# & - & - & - & + \\
\hline 20. & $\mathrm{PHO}$ & Phosphatase & + & + & + & + \\
\hline 21. & PRV & Pyruvate & - & - & - & - \\
\hline 22. & PYR & Pyrolidonyl arylamidase & - & - & - & - \\
\hline 23. & RAF & Raffinose & - & - & - & - \\
\hline 24. & RBS & Rambose & - & - & - & + \\
\hline 25. & SOR & Sorbitol & - & - & - & + \\
\hline 26. & TFG & Thymidine free growth & + & + & + & + \\
\hline 27. & TRE & Acidification trehalose & + & + & + & + \\
\hline 28. & URE & Urea & - & + & + & + \\
\hline 29. & VP & Voges-Proskauer & + & - & + & + \\
\hline
\end{tabular}

'-' (negative); '+' (positive); Gr.: Group; NR: Not reported; *PGR: p-nitro phenyl $\beta-D-$ glucuronide; \#PGT: p-nitro phenyl $\beta$-D-galactopyranoside.

Table 3: Effect of biofield treatment on Staphylococcus aureus to the biochemical reaction pattern

Table 2: Effect of biofield treatment on Staphylococcus aureus to minimum inhibitory concentration (MIC) value of tested antimicrobials.

of S. aureus in Gr. II did not show any alteration on both assessment time point with respect to either antimicrobial susceptibility or MIC values of tested antimicrobials except chloramphenicol (on day 10) as compared to control. Overall, the antimicrobial resistance pattern ( $\mathrm{S}$ to $\mathrm{R}$ ) and corresponding MIC values were significantly altered in lyophilized strain $S$. aureus after biofield treatment as compared to control.

\section{Biochemical reactions studies}

The specific biochemicals showed some changes against $S$. aureus after biofield treatment are shown in Table 3. Similarly, novobiocin, glycosidases, $\beta$-lactamases, rambose, sorbitol and glycosidase (PGR and PGT) were changed from negative $(-)$ to positive $(+)$ reaction in lyophilized treated group but remained same, i.e., negative (-) in revived treated cells with respective to control. Voges-Proskauer converted from positive (+) to negative (-) reaction in Gr. II on day 5 with respect to control in biofield treated $S$. aureus cells. Similarly, urea, arginine and MNS were converted from negative (-) to positive (+) reaction in all the groups as compared to control. Crystal violet converted from negative $(-)$ to positive (+) reaction in the treated groups (Gr. II and III) on day 10 while remained same, i.e., negative (-) in Gr. II on day 5. The key

characteristic feature for S. aureus are colony pigment, free coagulase, clumping factor, protein $\mathrm{A}$, heat-stable nuclease and acid production from mannitol [24]. In this experiment after biofield treatment due to production of acid from mannitol, result showed positive (+) reaction in all the groups which supports the characteristics feature of S. aureus. Overall, $37.93 \%$ biochemical reactions were altered in tested twenty nine biochemicals with respect to control after biofield treatment. In lyophilized treated S. aureus cells $34.48 \%$ on day 10 and revived treated cells $17.24 \%$ on day 5 and 10 , alteration of biochemical reactions were found as compared to control. About $58.62 \%$ of total biochemicals, such as arabinose, bacillosamine, bile esculin, Indoxyl phosphatase, inulin, acidification lactose, mannose, mannitol salt, sodium chloride, nitrate, optochin, phosphatase, pyruvate, pyrolidonyl arylamidase, raffinose, TFG, and acidification trehalose did not show any change in all the groups after biofield treatment as compared to control.

\section{Identification of organism by biotype number}

The species ( $S$. aureus) was identified based on variety of conventional biochemical characters and biotyping. Biotype number of particular organism was evaluated after interpreting the results of the biochemical reactions. The biotype number then led to the particular organism identification. In this experiment, biotyping was performed 
Citation: Trivedi MK, Patil S, Shettigar H, Mondal SC, Jana S (2015) Antimicrobial Susceptibility Pattern and Biochemical Characteristics of Staphylococcus aureus: Impact of Bio field Treatment. J Microb Biochem Technol 7: 238-241. doi:10.4172/1948-5948.1000215

\begin{tabular}{|c|c|c|c|c|}
\hline \multirow{2}{*}{ Feature } & \multirow{2}{*}{ Gr. I } & \multicolumn{2}{|c|}{ Gr. II } & \multirow{2}{*}{$\begin{array}{c}\text { Gr. III } \\
\text { Day } 10\end{array}$} \\
\hline & & Day 5 & Day 10 & \\
\hline Biotype & 307016 & 303137 & 707137 & 767177 \\
\hline $\begin{array}{l}\text { Organism } \\
\text { Identification }\end{array}$ & S. aureus & $\begin{array}{l}\text { Staphylococcus } \\
\text { capitis subsp. } \\
\text { ureolyticus }\end{array}$ & S. aureus & $\begin{array}{l}\text { Staphylococcus } \\
\text { cohnii subsp. } \\
\text { urealyticum }\end{array}$ \\
\hline
\end{tabular}

6. Burr HS (1957) Bibliography of Harold Saxton Burr. Yale J Biol Med 30: 163-167.

7. Hammerschlag R, Jain S, Baldwin AL, Gronowicz G, Lutgendorf SK, et al. (2012) Biofield research: A roundtable discussion of scientific and methodological issues. J Altern Complement Med 18: 1081-1086.

8. Movaffaghi Z, Farsi M (2009) Biofield therapies: Biophysical basis and biological regulations? Complement Ther Clin Pract 15: 35-37.

9. Rivera-Ruiz M, Cajavilca C, Varon J (2008) Einthoven's string galvanometer The first electrocardiograph. Tex Heart Inst J 35: 174-178.

Table 4: Effect of biofield treatment on biotype number of Staphylococcus aureus.

using automated systems, results found significant changes in the biofield treated Gr. II (on day 5) and Gr. III (on day 10). Based on the biochemical results, biotype number was changed in treated Gr. II on day 5 (303137, Staphylococcus capitis subsp. ureolyticus) and Gr. III on day 10 (767177, Staphylococcus cohnii subsp. urealyticum) with respect to control (307016), i.e., S. aureus (Table 4).

Due to microbial resistance to a single drug or multiple drugs, invention of an effective antimicrobial therapy for the human-wellness is urgently required. However, due to some limitation of science, the progress of new medications is slow and very challenging for scientists. Mr. Trivedi has the ability to harness energy from environment and altered the significant changes in microorganisms [15,16]. Biofield treatment might be responsible to do alteration in microorganism at genetic level and/or enzymatic level, which may act on receptor protein. While altering receptor protein, ligand-receptor/protein interactions may alter that could lead to show different phenotypic characteristics [25]. Biofield treatment might induce significant changes in lyophilized strain of $S$. aureus and altered antimicrobials susceptibility pattern, MIC values, biochemical reactions, and ultimately change the biotype number of microorganism. As a result, the microbe that was susceptible to a particular antimicrobial in control sample now converted into resistant/BLAC in lyophilized treated cells of $S$. aureus predominately after biofield treatment. Based on these results, it is postulated that, biofield treatment has the ability to alter the sensitivity pattern of antimicrobials.

\section{Conclusions}

Altogether, the biofield treatment has significant (86.67\%) altered the susceptibility pattern with MIC values of tested antimicrobials against the strain of $S$. aureus. It also significantly (37.93\%) altered the biochemical reactions pattern and biotype number of biofield treated strain of $S$. aureus. On the basis of changed biotype number after biofield treatment, new species were identified in revived cells as Staphylococcus capitis subsp. ureolyticus and in lyophilized cells as Staphylococcus cohnii subsp. urealyticum with respect to control, i.e., S. aureus. Mr. Trivedi's biofield treatment could be applied as alternative therapeutic approach against antimicrobial resistance.

\section{References}

1. Konuku S, Rajan MM, Muruhan S (2012) Morphological and biochemical characteristics and antibiotic resistance pattern of Staphylococcus aureus isolated from grapes. Int J Nut Pharmacol Neurol Dis 2: 70-73.

2. Balaban N, Rasooly A (2000) Staphylococcal enterotoxins. Int J Food Microbiol 61: 1-10.

3. Scherrer D, Corti S, Muehlherr JE, Zweifel C, Stephan R (2004) Phenotypic and genotypic characteristics of Staphylococcus aureus isolates from raw bulktank milk samples of goats and sheep. Vet Microbiol 101: 101-107.

4. Schlegelová J, Nápravníková E, Dendis M, Horváth R, Benedík J, et al. (2004) Beef carcass contamination in a slaughterhouse and prevalence of resistance to antimicrobial drugs in isolates of selected microbial species. Meat Sci 66: 557-565

5. Chakraborty SP, Mahapatra SK, Roy S (2011) Biochemical characters and antibiotic susceptibility of Staphylococcus aureus isolates. Asian Pac J Trop Biomed 1: 212-216.

10. Trivedi MK, Tallapragada RM (2008) A transcendental to changing metal powder characteristics. Met Powder Rep 63: 22-28,31.

11. Dabhade VV, Tallapragada RR, Trivedi MK (2009) Effect of external energy on atomic, crystalline and powder characteristics of antimony and bismuth powders. Bull Mater Sci 32: 471-479.

12. Trivedi MK, Tallapragada RM (2009) Effect of super consciousness external energy on atomic, crystalline and powder characteristics of carbon allotrope powders. Mater Res Innov 13: 473-480.

13. Sances F, Flora E, Patil S, Spence A, Shinde V (2013) Impact of biofield treatment on ginseng and organic b1lueberry yield. AGRIVITA J Agric Sci 35: 22-29.

14. Lenssen AW (2013) Biofield and fungicide seed treatment influences on soybean productivity, seed quality and weed community. Agricultural Journal 83: $138-143$.

15. Trivedi M, Patil S (2008) Impact of an external energy on Staphylococcus epidermis [ATCC -13518 ] in relation to antibiotic susceptibility and biochemical reactions - An experimental study. J Accord Integr Med 4: 230-235.

16. Trivedi M, S Patil (2008) Impact of an external energy on Yersinia enterocolitica [ATCC -23715] in relation to antibiotic susceptibility and biochemical reactions: An experimental study. Internet J Alternat Med 6: 2.

17. Trivedi M, Bhardwaj Y, Patil S, Shettigar H, Bulbule A (2009) Impact of an external energy on Enterococcus faecalis [ATCC - 51299] in relation to antibiotic susceptibility and biochemical reactions - An experimental study. J Accord Integr Med 5: 119-130.

18. Patil SA, Nayak GB, Barve SS, Tembe RP, Khan RR (2012) Impact of biofield treatment on growth and anatomical characteristics of Pogostemon cablin (Benth). Biotechnology 11: 154-162.

19. Altekar N, Nayak G (2015) Effect of biofield treatment on plant growth and adaptation. J Environ Health Sci 1: 1-9.

20. Fader RC, Weaver E, Fossett R, Toyras M, Vanderlaan J, et al. (2013) Multilaboratory study of the biomic automated well-reading instrument versus MicroScan WalkAway for reading MicroScan antimicrobial susceptibility and identification panels. J Clin Microbiol 51: 1548-1554.

21. Pereira EM, Schuenck RP, Malvar KL, lorio NL, Matos PD, et al. (2010) Staphylococcus aureus, Staphylococcus epidermidis and Staphylococcus haemolyticus: Methicillin-resistant isolates are detected directly in blood cultures by multiplex PCR. Microbiol Res 165: 243-249.

22. Toribio-Jimenez J, Moral BM, Echeverria SE, Pineda CO, Rodriguez-Barrera MA, et al. (2014) Biotype, antibiotype, genotype and toxin gene test-1 in Staphylococcus aureus isolated from cotija cheese in the state of Guerrero, Mexico. Afr J Microbiol Res 8: 2893-2897.

23. Milazzo I, Blandino G, Caccamo F, Musumeci R, Nicoletti G, et al. (2003) Faropenem, a new oral penem: Antibacterial activity against selected anaerobic and fastidious periodontal isolates. J Antimicrob Chemother 51: 721-725.

24. Ishii Y, Alba J, Maehara C, Murakami H, Matsumoto T, et al. (2006) Identification of biochemically atypical Staphylococcus aureus clinical isolates with three automated identification systems. J Med Microbiol 55: 387-392.

25. Lindstrom E, Hansson M, Lundgren E (1998) Analysis of the T cell activation signalling pathway during ELF magnetic field exposure, p56lck and [Ca2+] i-measurements. Bioeletrochem Bioenerg 46: 129-137.

Citation: Trivedi MK, Patil S, Shettigar H, Mondal SC, Jana S (2015) Antimicrobial Susceptibility Pattern and Biochemical Characteristics of Staphylococcus aureus: Impact of Bio field Treatment. J Microb Biochem Technol 7: 238-241. doi:10.4172/1948-5948.1000215 